\title{
IDENTIFICATION OF Ricinus communis HYBRIDS FOR LOW PLANT HEIGHT ${ }^{1}$
}

\author{
FREDSON DOS SANTOS MENEZES ${ }^{2 *}$, SIMONE ALVES SILVA ${ }^{3}$, GEAN CARLO SOARES CAPINAN ${ }^{4}$, HELISON \\ SANTOS BRASILEIRO ${ }^{3}$, LAURENICE ARAÚJO DOS SANTOS ${ }^{3}$
}

\begin{abstract}
Castor bean (Ricinus communis L.) is a plant native to Africa that presents important socioeconomic value for many countries, and has been the subject of breeding programs. In this context, the objective of this work was to identify genotypes with potential for improvement, focused on lowering plant height, using 19 hybrids and eight parents of $R$. communis. The study was developed at the experimental area of the Federal University of Recôncavo da Bahia in Cruz das Almas, BA, Brazil. The experiment was conducted in 2017 using a randomized block design with three replications, consisting of eight parents and 19 hybrids resulting from hybridization of these parents, grown with spacing of 3 meters between rows and 1 meter between plants. The characters stem diameter (SD), primary raceme insertion height (PRI), number of stem internodes (NSI), mean stem internode length (SIL), plant height (PH), number of harvested racemes (NHR), primary raceme length (PRL), and effective raceme length (ERL) were evaluated by analyzing the genetic parameters of variances and correlation between them. Five (H17, H2, H11, H13, and H6) of the 19 hybrids evaluated have potential to decrease PH of castor bean plants, presenting heights below $1.07 \mathrm{~m}$. Direct selection for plant height is the most indicated for this purpose due to the high heritability of the character. However, the characters SD, PRI, and SIL stood out by assisting in indirect selection to decrease plant height because they can be early measured and present high heritability and strong correlation with $\mathrm{PH}$.
\end{abstract}

Keywords: Breeding. Low height. Castor bean.

\section{IDENTIFICAÇÃO DE HÍBRIDOS DE RICINUS COMMUNIS L. PARA PORTE BAIXO}

RESUMO - A mamoneira (Ricinus communis L.) é uma planta de origem africana que apresenta importante valor socioeconômico para os países que a cultivam, o que vem implicando em investimentos em programas de melhoramento. Diante disso, o presente trabalho teve como objetivo identificar dentre 19 híbridos e oito parentais de $R$. communis, genótipos com potencial para melhoramento visando baixa estatura. O estudo foi desenvolvido na área experimental da Universidade Federal do Recôncavo da Bahia na cidade de Cruz das Almas, BA, sendo instalado em 2017 sob delineamento em blocos casualizados com três repetições, composto por oito parentais e 19 híbridos resultantes da hibridação dos parentais, no espaçamento 3 metros entre linhas e 1 metro entre plantas. Foram avaliados os caracteres: diâmetro do caule (DC), inserção do racemo primário (IRP), número de internódios do caule (NIC), comprimento médio dos internódios do caule (CMIC), estatura de planta (EP), número de racemos colhidos (NRC), comprimento do racemo primário (CRP) e comprimento efetivo do racemo (CER), sendo analisados os parâmetros genéticos de variâncias e correlação entre caracteres. Conclui-se que dos 19 híbridos avaliados, cinco são potenciais na redução de EP em mamoneira, sendo eles H17, H2, H11, H13 e H6, apresentando estatura abaixo de 1,07 m. A seleção direta para estatura de planta é a mais indicada pela presença da alta herdabilidade do caráter. Entretanto, os caracteres DC, IRP e CMIC se destacam no auxílio à seleção indireta para redução de estatura de planta por serem mensurados precocemente, apresentando alta herdabilidade e forte correlação com EP.

Palavras-chave: Melhoramento genético. Baixa estatura. Mamoneira.

\footnotetext{
*Corresponding author

${ }^{1}$ Received for publication in 06/29/2020; accepted in 07/22/2021.

${ }^{2}$ Center for Biotechnology and Genetics, Universidade Estadual de Santa Cruz, Ilhéus, BA, Brazil; fredson96@live.com - ORCID: 00000002-1186-7924.

${ }^{3}$ Center for Genetic Improvement, Universidade Federal do Recôncavo da Bahia, Cruz das Almas, BA, Brazil; sas@ufrb.edu.br - ORCID: 0000-0002-3017-6133, agr.brasileiro81@gmail.com - ORCID: 0000-0003-3608-6291, lasagro@hotmail.com - ORCID: 0000-0003-1367279X.

${ }^{4}$ General Teaching Coordination, Instituto Federal de Educação, Ciência e Tecnologia da Bahia, Itapetinga, BA, Brazil; gean.capinan@ifbaiano.edu.br-ORCID: 0000-0001-6189-7040.
} 


\section{INTRODUCTION}

The cultivation of castor bean (Ricinus communis L.; Euphorbiaceae) has high economic, social, and environmental importance; it is grown mainly for the oil extracted from its seeds, which is useful mainly for the manufacturing of biofuels and cosmetic and pharmacochemical products (MIRANDA et al., 2017; RUKHSAR et al., 2018). The largest castor bean producing countries are India, Mozambique, China, and Brazil. Brazil presented a mean yield of $951 \mathrm{Kg} \mathrm{ha}^{-1}$ in 2020, totaling 43,300 tons; the state of Bahia was the main state responsible for this production (CONAB, 2020; FAO, 2019; IBGE, 2019). This oilseed species is grown mainly by family farmers in small properties; however, the low technological level of these farms, mainly due to the absence of agricultural machinery for soil preparation, proper cultivation management, and improved and adapted cultivars to the different producing regions, limits its yield (LINS; SOUSA, 2019; VAZ; SAMPAIO; SAMPAIO, 2010). Low plant height is important for $R$. communis to determine plant density, which may contribute to the adaptability of plants to different environments for single or intercropped cultivation (LISBOA et al., 2018; SORATTO et al., 2011). The development of castor bean plants with low heights may allow their growth in denser systems, which provides better area use, generating a higher production, and higher yields, since plants grown under denser systems present better light interception and significant decreases in vegetative drains (PIVETTA et al., 2017). Although this morphoagronomic characteristic have been a main target in breeding programs, the results regarding decreases in height have not been satisfactory (SILVA et al., 2017). These and other results are often achieved by developing hybrids, which is a technique focused on combining the maximum number of favorable characters in one genotype (CARVALHO et al.,
2008). The estimating of genetic parameters of the populations resulting from hybridization, with identification of genetic, environmental, and phenotypic variances are important to assist in guiding the selection for different characters, such as the expression of the plant height character (CRUZ; REGAZZI; CARNEIRO, 2012; PASSOS et al., 2010). Thus, hybridization of divergent lines for the plant height character could favor the emergence of plants with lower heights than their parents. However, there is no studies focused on the development of hybrids to decrease $R$. communis plant height nor on important genetic parameters for this character.

Thus, the objective of this work was to identify genotypes with potential for improvement, focused on lowering plant height, using 19 hybrids and eight parents of $R$. communis.

\section{MATERIAL AND METHODS}

\section{Plant material}

Nineteen hybrids and eight parent lines were evaluated (Table 1); they belonged to the Castor Bean Breeding Program of the Federal University of Recôncavo da Bahia (UFRB), Cruz das Almas, BA, Brazil $\left(12^{\circ} 40^{\prime} 19^{\prime \prime} \mathrm{S} ; 3^{\circ} 06^{\prime} 22^{\prime \prime} \mathrm{W}\right.$, and $226 \mathrm{~m}$ of altitude). The region has a tropical climate with mean annual temperature of $24.5{ }^{\circ} \mathrm{C}$, relative air humidity of $80 \%$, and annual rainfall depth of approximately $1.170 \mathrm{~mm}$ (REZENDE, 2004). The choice of lines was based on previous tests that considered the genetic dissimilarity between the genotypes, and results after artificial hybridizations, consisted of controlled crossings between the parents carried out in the flowering stage, using manual emasculation of the plant (female parent) with the aid of tweezers and subsequent pollination with the plant pollen (male parent) to obtain the hybrids.

Table 1. Hybrids and parents evaluated. Cruz das Almas, BA, Brazil.

\begin{tabular}{|c|c|c|c|c|c|c|c|}
\hline \multicolumn{2}{|r|}{ Lines } & \multicolumn{2}{|c|}{ Hybrids } & \multicolumn{2}{|c|}{ Hybrids } & \multicolumn{2}{|c|}{ Hybrids } \\
\hline $\mathrm{P} 1$ & UFRB 79 & $\mathrm{H} 1$ & $176 \times 248$ & H9 & $79 \times 36$ & H17 & $160 \times 36$ \\
\hline $\mathrm{P} 2$ & UFRB 36 & $\mathrm{H} 2$ & $36 \times 248$ & H10 & $79 \times 122$ & H18 & $79 \times 176$ \\
\hline P3 & UFRB 122 & $\mathrm{H} 3$ & $255 \times 176$ & H11 & $176 \times 79$ & H19 & $176 \times 36$ \\
\hline $\mathrm{P} 4$ & UFRB 160 & H4 & $160 \times 176$ & H12 & $176 \times 193$ & & \\
\hline P5 & UFRB 176 & H5 & $193 \times 176$ & H13 & $122 \times 79$ & & \\
\hline P6 & UFRB 193 & H6 & $255 \times 122$ & H14 & $36 \times 193$ & & \\
\hline $\mathrm{P} 7$ & UFRB 248 & $\mathrm{H} 7$ & $193 \times 36$ & H15 & $79 \times 193$ & & \\
\hline P8 & UFRB 255 & $\mathrm{H} 8$ & $36 \times 122$ & H16 & $36 \times 176$ & & \\
\hline
\end{tabular}


The experiment was implemented on May 11, 2017 , with conventional soil preparation of the area, using one plowing and one harrowing, followed by the sowing in pits using three seeds per pit; a thinning was carried out at five weeks after the emergence, leaving only one plant per pit. The soil acidity and fertility were corrected based on the soil chemical analysis (SAVY FILHO, 2005), using dolomitic limestone $\left(200 \mathrm{~kg} \mathrm{ha}^{-1}\right), \mathrm{N}\left(60 \mathrm{~kg} \mathrm{ha}^{-1}\right.$; $20 \mathrm{~kg} \mathrm{ha}^{-1}$ at planting and $40 \mathrm{~kg} \mathrm{ha}^{-1}$ as topdressing), $\mathrm{P}_{2} \mathrm{O}_{5}\left(80 \mathrm{~kg} \mathrm{ha}^{-1}\right)$, and $\mathrm{K}_{2} \mathrm{O}\left(40 \mathrm{~kg} \mathrm{ha}^{-1}\right)$. Weed control was carried out using mechanical hoeing between rows and manual hoeing between plants. Fungicide (Sumilex $500 \mathrm{WP}$ ) was used as needed for the control of mold (Amphobotrys ricini) during the experiment.

\section{Experimental design}

A randomized block experimental design was used, with three replications. Each plot consisted of one 12 meter row. The spacing used was $3 \mathrm{~m}$ between rows and $1 \mathrm{~m}$ between plants in the rows, resulting in 12 plants per row; the evaluation were conducted in an area of $30 \mathrm{~m}^{2}$ with 10 plants per plot.

\section{Agronomic evaluations}

The genotypes were evaluated according to the descriptors of castor bean plants proposed by the Brazilian Ministry of Agriculture, Livestock and Food Supply (MAPA) (MILANI, 2008) and others described by the Center for Genetic and Biotechnological Improvement (NBIO) (SILVA et al., 2019). Eight quantitative descriptors were measured:

1) Stem diameter (SD), measured in the middle third of the stem using a digital caliper with $0.01 \mathrm{~mm}$ precision and classified as 1 . Thin $(<3 \mathrm{~cm})$, 2. Medium ( 3 to $5 \mathrm{~cm}$ ), or 3 . Long $(>5 \mathrm{~cm}$ ).

2) Primary raceme insertion height (PRI), measured from the ground to the first raceme insertion point using a tape measure $(\mathrm{cm})$ and classified as 1 . Low $(<50 \mathrm{~cm}), 2$. Medium (51 to 100 $\mathrm{cm})$, or 3 . High $(>100 \mathrm{~cm})$.

3) Number of stem internodes (NSI), counted using the quantity of scars in the stem and classified as 1 . Low $(\leq 15), 2$. Medium (16 to 18$)$, or 3 . High $(>19 \mathrm{~cm})$.

4) Mean stem internode length (SIL), obtained by the NSI to PRI ratio and classified as 1 . Short $(<2 \mathrm{~cm}), 2$. Medium (2 to $5 \mathrm{~cm})$, or 3 . Long ( $>$ $5 \mathrm{~cm})$.

5) Plant height $(\mathrm{PH})$, measured from the ground to the apex of the highest branch of the plant with the aid of a tape measure $(\mathrm{cm})$ and classified as 1. Very low $(<100 \mathrm{~cm}), 2$. Low (101 to $150 \mathrm{~cm}), 3$. Medium (151 to $200 \mathrm{~cm}), 4$. High $(201$ to $250 \mathrm{~cm})$, or 5 . Very high $(>250 \mathrm{~cm})$.
6) Number of harvested racemes (NHR), counted using the quantity of racemes emitted per plant and classified as 1 . Low $(\leq 3), 2$. Medium (3 to 7 ), or 3. High ( $>7)$.

7) Primary raceme length (PRL), measured from the apex of the first raceme to the scar of the first internode using a ruler $(\mathrm{mm})$ and classified as 1 . Short $(<31 \mathrm{~cm}), 2$. Medium $(31$ to $50 \mathrm{~cm})$, or 3 . Long $(>50 \mathrm{~cm})$.

8) Effective raceme length (ERL), measured by the distance between the raceme apex to the last peduncle and classified as 1 . Short $(<31 \mathrm{~cm}), 2$. Medium (31 to $50 \mathrm{~cm})$, or 3 . Long $(>50 \mathrm{~cm})$.

The characters SD, PRI, NSI, and SIL were measured at the full flowering phenological stage of the primary raceme, i.e., when the primary raceme presented developed male and female flowers. The characters PH, NHR, PRL, and ERL were measured at the full flowering phenological stage of the last commercial raceme.

\section{Statistical analyses}

The data were subjected to analysis of variance (ANOVA) at 1\% significance, grouping of means (Scott-Knott test) at 5\% significance, and Pearson's correlation, using the $\mathrm{R}$ 3.3.4 program (R DEVELOPMENT CORE TEAM, 2017) with the Agricolae package.

The phenotypic (Vp), genotypic $(\mathrm{Vg})$, and environmental (Ve) variances, heritability $\left(h^{2}\right)$, coefficients of environmental (CVe) and genotypic $(\mathrm{CVg})$ variation, and $\mathrm{CVg}$ to $\mathrm{CVe}$ ratio were estimated according to the equations proposed by Cruz, Regazzi and Carneiro (2012):

$$
\begin{aligned}
& V p=Q M G / r \\
& V g=(Q M G-Q M R) / r \\
& V e=Q M R / r \\
& h^{2}=(V g / V p) \cdot 100 \\
& C V g=(\sqrt{V g} / \bar{X}) \cdot 100 \\
& C V e=(\sqrt{V e} / \bar{X}) \cdot 100
\end{aligned}
$$

where QMG, QMR, r, and $\bar{X}$ represent the mean square of genotype, mean square of the residue, number of replications, and mean. respectively.

\section{RESULTS AND DISCUSSION}

The analysis of variance (ANOVA) allowed the identification of significant differences $(p<0.01)$ for all evaluated characters (Table 2), with coefficients of variation (CV) varying from $4.66 \%$ to $20.08 \%$. 
Table 2. Analysis of variance for morphoagronomic characters of parents and hybrids of $R$. communis for low plant height. Cruz das Almas, BA, Brazil.

\begin{tabular}{cccccccccc}
\hline \multicolumn{10}{c}{ Mean squares } \\
\hline \multirow{2}{*}{ Sources of variation } & DF & SD (cm) & PRI (cm) & NSI & SIL (cm) & PH (cm) & NHR & PRL (cm) & ERL (cm) \\
\hline Blocks & 2 & 0.312 & 137.442 & 14.207 & 1.970 & 5790.242 & 20.882 & 27.504 & 31.657 \\
Genotypes & 26 & $0.183^{* *}$ & $185.556^{* *}$ & $4.635^{* *}$ & $0.682^{* *}$ & $1441.594^{* *}$ & $6.610^{* *}$ & $124.648^{* *}$ & $74.422^{* *}$ \\
Residue & 52 & 0.034 & 26.870 & 0.627 & 0.075 & 215.814 & 1.175 & 9.526 & 8.561 \\
\hline Total & 80 & & & & & & & & \\
\hline Mean & & 2.10 & 60.26 & 17.00 & 3.56 & 118.27 & 5.40 & 28.23 & 19.95 \\
\hline CV (\%) & & 8.75 & 8.60 & 4.66 & 7.70 & 12.42 & 20.08 & 10.93 & 14.66 \\
\hline
\end{tabular}

** $=$ significant at $1 \%$ probability level by the $\mathrm{F}$ test. $\mathrm{DF}=$ degrees of freedom, $\mathrm{SD}=$ stem diameter, $\mathrm{PRI}=$ primary raceme insertion height, $\mathrm{NSI}=$ number of stem internodes, $\mathrm{SIL}=$ mean stem internode length, $\mathrm{PH}=$ plant height, $\mathrm{NHR}=$ number of harvested racemes, $\mathrm{PRL}=$ primary raceme length, $\mathrm{ERL}=$ effective raceme length.

The morphoagronomic characters evaluated showed significant differences, denoting the existence of variability between the hybrids and parents (Table 2), which is essential to identify superior genotypes for these characters and obtain genetic gains through selection (TORRES et al., 2015). The CV varied from 4.66 to 20.08 for the characters evaluated. The characters measured at the full flowering phenological stage of the primary raceme (SD, PRI, NSI, and SIL) presented lower $\mathrm{CV}$, since they are determined early, minimizing the effect of the environment and the variation of results (CARVALHO et al., 2008). All the characters measured later (PH, PRL, ERL, and NRC), at the full flowering stage of the last commercial raceme presented higher $\mathrm{CV}$, denoting that they were more affected by the effect of the environment. Rodrigues et al. (2010) evaluated 15 castor bean accessions and also found similar $\mathrm{CV}$ for the same characters evaluated in the present work.

The 19 hybrids and eight parents were grouped using the Scott-Knott test at 5\% significance $(\mathrm{p}<0.05)$ for all characters evaluated (Table 3$)$.

The character stem diameter formed four groups (Table 3 ) with mean of $2.10 \mathrm{~cm}$ and variation range of $1.41 \mathrm{~cm}(\mathrm{H} 17)$ to $2.53 \mathrm{~cm}(\mathrm{H} 8)$. Group A presented the highest number of genotypes with predominance of higher SD $(59.25 \%)$, denoting the potential for selection of genotypes with diameters up to $2.53 \mathrm{~cm}$, mainly for the hybrid H6. The genotype $\mathrm{H} 17$ was in the group $\mathrm{D}$, presenting the lowest SD $(1.41 \mathrm{~cm})$.

According to Formiga et al. (2014), a high SD is important to avoid occurrences of lodging when there is absence of water restrictions, mainly in regions with strong and frequent winds. However, according to Soratto et al. (2012), a high SD is not desirable when prioritizing mechanized harvest.
Group A had predominance of high SD (diameters of up to $2.53 \mathrm{~cm}$ ), which can enable the selection of hybrids resistant to lodging. However, the hybrid H17 can be selected when prioritizing mechanized harvest, since it presented the lowest mean SD.

The primary raceme insertion height formed three groups, with mean of $60.26 \mathrm{~cm}$ and variation range of $47.02 \mathrm{~cm}(\mathrm{H} 17)$ to $80.42 \mathrm{~cm}$ (H8). Group B included intermediate values, presenting the highest number of genotypes $(66.66 \%)$. However, $25.92 \%$ of genotypes (H17, P3, H2, P8, H13, H11, and H1) presented lower PRI, varying from 47.02 (H17) to $55.22(\mathrm{H} 1) \mathrm{cm}$.

According to Rodrigues et al. (2010), plants with low PRI will express a low height, and may be less productive. Mateus et al. (2015) found that PRI is related to plant precocity; plants with early maturation are those that emit the first bunch with lower heights. The hybrids with low PRI are the most important for breeding programs, they represented $25.96 \%$ of the genotypes evaluated (H17, H2, H13, H11 and H1). The hybrids with low PRI also presented low PH, except the hybrid H1.

The mean stem internode length formed five groups, with mean of $3.56 \mathrm{~cm}$ and variation range of $2.70 \mathrm{~cm}$ (H17) to $4.63 \mathrm{~cm} \mathrm{(P7).} \mathrm{Group} \mathrm{C}$ was predominant $(48.14 \%)$, presenting values from 3.38 $\mathrm{cm}(\mathrm{H} 10)$ to $3.80 \mathrm{~cm}$ (H6). However, potential for selection for low SIL was shown by $14.81 \%$ of the genotypes, which presented lower variations, 2.70 (H17) to $3.01(\mathrm{H} 2)$, in group A.

The number of stem internodes formed four groups, with mean of 17.00 internodes and variation range of 13.09 (P7) to 18.42 (P6). Most genotypes were in group $\mathrm{A}$, with the highest means for this character $(77.77 \%)$, varying from 16.52 (H14) to 18.42 (P6) internodes. 
Table 3. Groups formed by 19 hybrids and eight parents of $R$. communis considering the means of morphoagronomic characters. Cruz das Almas, BA, Brazil.

\begin{tabular}{|c|c|c|c|}
\hline \multicolumn{4}{|c|}{ Stem diameter (SD) } \\
\hline Groups & Genotypes & Number of genotypes & Variation range $(\mathrm{cm})$ \\
\hline a & $\begin{array}{c}\mathrm{H} 8, \mathrm{P} 6, \mathrm{H} 16, \mathrm{H} 18, \mathrm{P} 1, \mathrm{H} 3, \mathrm{H} 4, \mathrm{H} 15, \mathrm{H} 9, \mathrm{P} 7, \mathrm{H} 10, \mathrm{H} 12, \\
\text { H14, H5, P5, and H6 }\end{array}$ & 16 & $2.53-2.09$ \\
\hline $\mathrm{b}$ & $\mathrm{H} 4, \mathrm{H} 3, \mathrm{H} 13, \mathrm{P} 2, \mathrm{H} 1, \mathrm{H} 2, \mathrm{H} 11$, and $\mathrm{P} 3$ & 8 & $2.03-1.81$ \\
\hline $\mathrm{c}$ & $\mathrm{P} 4$, and $\mathrm{P} 8$ & 2 & $1.76-1.70$ \\
\hline d & $\mathrm{H} 17$ & 1 & $1.41-1.41$ \\
\hline \multicolumn{4}{|c|}{ Primary raceme insertion height (PRI) } \\
\hline a & $\mathrm{H} 17, \mathrm{P} 3, \mathrm{H} 2, \mathrm{P} 8, \mathrm{H} 13, \mathrm{H} 11$, and $\mathrm{H} 1$ & 7 & $47.02-55.22$ \\
\hline $\mathrm{b}$ & $\begin{array}{c}\mathrm{P} 4, \mathrm{H} 5, \mathrm{P} 2, \mathrm{H} 12, \mathrm{H} 6, \mathrm{H} 19, \mathrm{P} 7, \mathrm{H} 10, \mathrm{H} 14, \mathrm{H} 9, \mathrm{P} 5, \mathrm{H} 7, \\
\mathrm{H} 15, \mathrm{H} 4, \mathrm{H} 3, \mathrm{P} 1, \mathrm{H} 18 \text {, and H16 }\end{array}$ & 18 & $57.67-68.51$ \\
\hline $\mathrm{c}$ & $\mathrm{P} 6$, and $\mathrm{H} 8$ & 2 & $75.27-80.42$ \\
\hline \multicolumn{4}{|c|}{ Number of stem internodes (NSI) } \\
\hline a & $\begin{array}{l}\mathrm{P} 6, \mathrm{H} 8, \mathrm{P} 2, \mathrm{H} 18, \mathrm{H} 10, \mathrm{H} 15, \mathrm{H} 5, \mathrm{P} 4, \mathrm{H} 4, \mathrm{P} 5, \mathrm{P} 1, \mathrm{H} 13, \\
\text { H17, H7, H16, H19, P3, H12, H11, H9, and H14 }\end{array}$ & 21 & $18.42-16.52$ \\
\hline $\mathrm{b}$ & $\mathrm{H} 2, \mathrm{H} 1, \mathrm{H} 6$, and $\mathrm{P} 8$ & 4 & $15.98-15.27$ \\
\hline $\mathrm{c}$ & $\mathrm{H} 3$ & 1 & $14.53-14.53$ \\
\hline $\mathrm{d}$ & P7 & 1 & $13.09-13.09$ \\
\hline \multicolumn{4}{|c|}{ Mean stem internode length (SIL) } \\
\hline $\mathrm{a}$ & $\mathrm{H} 17, \mathrm{P} 3, \mathrm{H} 13$, and $\mathrm{H} 2$ & 4 & $2.70-3.01$ \\
\hline $\mathrm{b}$ & $\mathrm{H} 11, \mathrm{P} 4, \mathrm{H} 5, \mathrm{P} 2$, and $\mathrm{P} 8$ & 5 & $3.14-3.31$ \\
\hline c & $\begin{array}{c}\mathrm{P} 4 \text {, and } \mathrm{P} 8 \mathrm{H} 10, \mathrm{P} 5, \mathrm{H} 19, \mathrm{H} 1, \mathrm{H} 12, \mathrm{H} 15, \mathrm{H} 4, \mathrm{H} 9, \mathrm{P} 1, \mathrm{H} 7, \\
\mathrm{H} 14, \mathrm{H} 18 \text {, and } \mathrm{H} 6\end{array}$ & 13 & $3.38-3.80$ \\
\hline $\mathrm{d}$ & $\mathrm{H} 16$, and P6 & 2 & $3.98-4.09$ \\
\hline $\mathrm{e}$ & $\mathrm{H} 8, \mathrm{H} 3$, and $\mathrm{P} 7$ & 3 & $4.42-4.63$ \\
\hline \multicolumn{4}{|c|}{ Plant height (PH) } \\
\hline a & $\mathrm{H} 17$, and $\mathrm{P} 3$ & 2 & $69.28-75.67$ \\
\hline $\mathrm{b}$ & $\mathrm{H} 2, \mathrm{P} 2, \mathrm{P} 8, \mathrm{H} 11, \mathrm{P} 4, \mathrm{H} 13$, and $\mathrm{H} 6$ & 7 & $89.24-107.20$ \\
\hline $\mathrm{c}$ & $\begin{array}{c}\text { P7, H14, H1, H4, H3, H5, H9, H18, P1, H10, H15, H12, } \\
\text { H19, H16, P5, H7, P6, and H8 }\end{array}$ & 18 & $115.00-154.07$ \\
\hline \multicolumn{4}{|c|}{ Number of harvested racemes (NHR) } \\
\hline a & $\mathrm{H} 12, \mathrm{H} 19$, and P5 & 3 & $8.82-7.78$ \\
\hline $\mathrm{b}$ & $\mathrm{H} 1, \mathrm{H} 4, \mathrm{P} 7, \mathrm{H} 16, \mathrm{H} 18, \mathrm{H} 7$, and $\mathrm{H} 8$ & 7 & $6.95-6.28$ \\
\hline $\mathrm{c}$ & $\begin{array}{c}\mathrm{H} 8, \mathrm{H} 15, \mathrm{H} 10, \mathrm{P} 1, \mathrm{H} 9, \mathrm{P} 6, \mathrm{H} 2, \mathrm{H} 13, \mathrm{H} 5, \mathrm{P} 8, \mathrm{P} 4, \mathrm{H} 14, \\
\mathrm{H} 3, \mathrm{H} 11, \mathrm{H} 6, \mathrm{P} 2, \mathrm{H} 17 \text {, and P3 }\end{array}$ & 18 & $5.76-3.02$ \\
\hline \multicolumn{4}{|c|}{ Primary raceme length (PRL) } \\
\hline $\mathrm{a}$ & $\mathrm{H} 8, \mathrm{H} 16, \mathrm{H} 14$, and $\mathrm{H} 9$ & 4 & $41.89-38.52$ \\
\hline $\mathrm{b}$ & $\mathrm{P} 2, \mathrm{H} 3$, and $\mathrm{H} 10$ & 3 & $34.14-31.93$ \\
\hline $\mathrm{c}$ & H6, P1, P6, H15, H4, H19, H7, H5, H13, P3, H18, and P7 & 12 & $29.82-25.13$ \\
\hline $\mathrm{d}$ & $\mathrm{H} 2, \mathrm{P} 4, \mathrm{H} 12, \mathrm{H} 1, \mathrm{H} 11, \mathrm{P} 8, \mathrm{P} 5$, and $\mathrm{H} 17$ & 8 & $24.22-16.25$ \\
\hline \multicolumn{4}{|c|}{ Effective raceme length (ERL) } \\
\hline $\mathrm{a}$ & $\mathrm{H} 8, \mathrm{H} 14$ and $\mathrm{H} 16$ & 3 & $31.62-28.24$ \\
\hline $\mathrm{b}$ & $\mathrm{H} 9, \mathrm{P} 2, \mathrm{H} 3$ and $\mathrm{P} 1$ & 4 & $25.87-22.98$ \\
\hline $\mathrm{c}$ & $\begin{array}{c}\mathrm{H} 10, \mathrm{H} 6, \mathrm{P} 3, \mathrm{P} 6, \mathrm{H} 2, \mathrm{H} 13, \mathrm{H} 15, \mathrm{P} 7, \mathrm{H} 19, \mathrm{H} 7, \mathrm{H} 1, \mathrm{H} 4, \\
\mathrm{H} 18, \mathrm{P} 8, \mathrm{H} 5 \text { and P4 }\end{array}$ & 16 & $21.67-16.47$ \\
\hline $\mathrm{d}$ & $\mathrm{H} 12, \mathrm{H} 11, \mathrm{H} 17$ and $\mathrm{P} 5$ & 4 & $15.12-11.22$ \\
\hline
\end{tabular}

Lowercase letters correspond to the groups formed according to the Scott-Knott test at 5\% significance for the respective characters. P: parent; H: hybrid.

The results of NSI should be interpreted together with the results of SIL, since the ideal plant is that that present the highest NSI and lower mean lengths. A high NSI may assure a better robustness to the plant, minimizing lodging and improving light use (SANTOS; VENCOVSKY, 1986). Pinto et al. (2011a) reported that a low SIL result in a plant with low height, favoring the partition of photoassimilates for the formation of castor bean seeds. It was also found in the present work, by the significant negative correlation between these characters, i.e., when the SIL increases, the PH decreases. In fact, the parent 
line 3 and the hybrid H17, which present low SIL and high NSI, also presented low $\mathrm{PH}$.

Plant height formed three groups, with mean of $118.27 \mathrm{~cm}$ and variation range of $69.28 \mathrm{~cm}(\mathrm{H} 17)$ to $154.07 \mathrm{~cm}(\mathrm{H} 8)$. Group $\mathrm{C}$ was predominant $(66.66 \%)$, with heights varying from $115 \mathrm{~cm}(\mathrm{P} 7)$ to $154.07 \mathrm{~cm}(\mathrm{H} 8)$. However, the group of plants of with the lowest heights represented $7.40 \%$ of the population, varying from $69.28 \mathrm{~cm}(\mathrm{H} 17)$ to 75.67 cm (P3). Genotypes with low PH (below $1.07 \mathrm{~m}$ ) were identified, including the hybrids $\mathrm{H} 17, \mathrm{H} 2, \mathrm{H} 11$, H13, and H6, which are promising for the improvement of this character.

Soratto et al. (2011) reported that plants with low heights facilitate manual and mechanized harvests, favoring the introduction of new technologies for cultivation of castor bean. The identification of genes involved in the control of $\mathrm{PH}$, followed by studies to decrease this character, is frequent in breeding programs, mainly for maize (LIU et al., 2017); and rice (WU et al., 2014) crops.

The number of harvested racemes formed three groups, with a mean of 5.40 racemes harvested per plant, and variation range of $3.02(\mathrm{P} 3)$ to 8.82 (H12). Group C predominated $(66.60 \%)$, presenting a variation range of $3.02(\mathrm{P} 3)$ to $5.76(\mathrm{H} 8)$ racemes per plant. However, group A (11.11\%) included the genotypes that presented the highest number of racemes, varying from 7.78 (P5) to 8.82 (H12). Moreover, NHR is directly correlated with yield (PUTTINI, 2014; SILVA et al., 2017). The hybrids H12, H19 and parent P5 stood out among the genotypes. The values found were expected, since Oliveira Neto et al. (2019) evaluated the character NHR and found the predominance of genotypes within the range of 1.66 to 4.33 , and the maximum number obtained for NHR was 10.33 .

The primary raceme length formed four groups, with mean of $28.23 \mathrm{~cm}$ and variation range of $16.25 \mathrm{~cm} \mathrm{(H17)} \mathrm{to} 41.89 \mathrm{~cm}$ (H8). Group C predominated $(44.44 \%)$, with lengths varying from 25.13 (P7) to 29.82 (H6) cm. However, the genotypes in the group that presented the highest means $(14.81 \%)$ showed a variation of 38.52 (H9) to 41.89 (H8).

The effective raceme length formed four groups, with mean of $19.95 \mathrm{~cm}$, and variation range of $11.22 \mathrm{~cm}$ (P5) to $31.62 \mathrm{~cm} \mathrm{(H8).} \mathrm{Group} \mathrm{C}$ included the genotypes with the highest values, varying from $16.47(\mathrm{P} 4)$ to $21.67(\mathrm{H} 10)$.

The results referring to phenotypic, genotypic, and environmental variances, heritability in the broad sense, coefficient of genetic variation, and coefficient of genetic variation to coefficient of environment variation ratio for all characters measured are shown in Table 4.

Table 4. Estimates of phenotypic $(\mathrm{Vp})$, genotypic $(\mathrm{Vg})$, and environmental $(\mathrm{Ve})$ variance, heritability in the broad sense $\left(\mathrm{h}^{2}\right)$, coefficient of genotypic variation $(\mathrm{CVg})$ and coefficient of genotypic variation to coefficient of environmental variation ratio $(\mathrm{CVg} / \mathrm{CVe})$ for morphoagronomic characters of eight parents and 19 hybrids of $R$. communis. Cruz das Almas, BA, Brazil.

\begin{tabular}{ccccccccc}
\hline & \multicolumn{7}{c}{ Characters } \\
\hline Parameters Genetic & SD & PRI & NSI & SIL & PH & NHR & PRL & ERL \\
\hline Vp & 0.061 & 61.852 & 1.545 & 0.227 & 480.531 & 2.203 & 41.549 & 24.807 \\
Vg & 0.050 & 52.895 & 1.336 & 0.202 & 408.593 & 1.811 & 38.374 & 21.953 \\
$\mathrm{Ve}$ & 0.011 & 8.957 & 0.209 & 0.025 & 71.938 & 0.392 & 3.175 & 2.854 \\
$\mathrm{~h}^{2}(\%)$ & 81.66 & 85.52 & 86.47 & 88.95 & 85.03 & 82.22 & 92.36 & 88.50 \\
$\mathrm{CVg}(\%)$ & 10.66 & 12.07 & 6.80 & 12.61 & 17.09 & 24.94 & 21.95 & 23.48 \\
$\mathrm{CVg} / \mathrm{CVe}$ & 1.218 & 1.403 & 1.460 & 1.638 & 1.376 & 1.241 & 2.007 & 1.601 \\
\hline
\end{tabular}

$\mathrm{SD}=$ stem diameter, $\mathrm{PRI}=$ primary raceme insertion height, $\mathrm{NSI}=$ number of stem internodes, $\mathrm{SIL}=$ mean stem internode length, $\mathrm{PH}=$ plant height, $\mathrm{NHR}=$ number of harvested racemes, $\mathrm{PRL}=$ primary raceme length, $\mathrm{ERL}=$ effective raceme length.

The effect of the genetic variance had a high contribution to the variation presented by the genotypes for all evaluated characters, denoting a low effect of the environment for the expression of these characters and, consequently, in the high heritability in the broad sense $\left(\mathrm{h}^{2}\right)$ found $(81.66 \mathrm{a}$ $92.36 \%)$. The coefficients of genetic variation $(\mathrm{CVg})$ of all characters were higher than the environmental variance $(\mathrm{Ve})$, resulting in a $\mathrm{CVg} / \mathrm{CVe}$ higher than 1.00 for all measured characteristics, especially for 
the character PRL, which presented a $\mathrm{CVg} / \mathrm{CVe}$ of 2.00. The $\mathrm{CVg} / \mathrm{CVe}$ showed to be directly related to $\mathrm{h}^{2}$ (Table 4).

The expression of characters by the hybrids and parents can be more efficiently explained through the intensity that genetic, environmental, and phenotypic variations affect the selection, with heritability as the most important parameter for the decision making to identify promising genotypes. Thus, the high genetic variance estimated for the characteristics indicated a minimum effect of the environment on the hybrids, which is not very common. A study on Manihot sculenta Crantz plants, which belong to the same family of $R$. communis, showed low environmental effect on hybrids, indicating a high genetic control of the evaluated characteristics (GEBREMICHEAL; NEBIYU; MULUALEM, 2015). High estimated values for $h^{2}$ indicate a high contribution of genotypic effects to the determination of the desired phenotype (RAMALHO et al., 2012). Therefore, the selection based on these hybrids are important to plan advances in breeding programs for this species.

The $\mathrm{CVg}$ and $\mathrm{CVg} / \mathrm{CVe}$ found indicated the presence of genetic variability. Thus, further studies for selection with crossing between the evaluated hybrids or with genotypes from other populations could provide a continuous improvement for the production of $R$. communis, since the evaluated genotypes presented high heritability and genetic variation with minimum environmental effect.

Another genetic parameter that assists breeders in the selection of superior genotypes is the correlation presented in Table 5. SD was positively correlated with all characters, except NSI. The highest correlations of SD were with $\mathrm{PH}$ and with PRI (0.812 and 0.757 , respectively). The character PRI presented significantly correlations to all characters; the highest correlations of PRI were with SIL and PH (0.786 and 0.748 , respectively). The character NSI presented significant negative correlation to SIL and positive to PRI. NHR were significantly correlated with the characters SD, PRI, SIL, and PH. High positive correlation (0.907) were found between PRL and ERL. PRL was significantly correlated with all characters evaluated, except NSI and NHR. ERL were significantly correlated with all characters, except NSI and NHR.

Table 5. Pearson's correlation between morphoagronomic characters of eight parents and 19 hybrids of $R$. communis for low plant height. Cruz das Almas, BA, Brazil.

\begin{tabular}{|c|c|c|c|c|c|c|c|c|}
\hline & SD & PRI & NSI & SIL & PH & NHR & PRL & ERL \\
\hline $\mathrm{SD}$ & 1 & & & & & & & \\
\hline PRI & $0.757 * *$ & 1 & & & & & & \\
\hline NSI & $0.189^{\mathrm{ns}}$ & $0.245 *$ & 1 & & & & & \\
\hline SIL & $0.599 * *$ & $0.786 * *$ & $-0.396 * *$ & 1 & & & & \\
\hline $\mathrm{PH}$ & $0.812 * *$ & $0.748 * *$ & $0.055^{\mathrm{ns}}$ & $0.662 * *$ & 1 & & & \\
\hline NHR & $0.606 * *$ & $0.411 * *$ & $-0.076^{\mathrm{ns}}$ & $0.435 * *$ & $0.744 * *$ & 1 & & \\
\hline PRL & $0.558 * *$ & $0.547 * *$ & $0.184^{\text {ns }}$ & $0.396 * *$ & $0.355 * *$ & $0.005^{\mathrm{ns}}$ & 1 & \\
\hline ERL & $0.407 * *$ & $0.452 * *$ & $-0.025^{\mathrm{ns}}$ & $0.428 * *$ & $0.251 *$ & $-0.060^{\mathrm{ns}}$ & $0.907 * *$ & 1 \\
\hline
\end{tabular}

$*_{*}^{*}=$ significant at $1 \%$ probability level by the $\mathrm{t}$ test; $*=$ significant at $5 \%$ probability level by the $\mathrm{t}$ test; ${ }^{\mathrm{ns}}=$ not significant. $\mathrm{SD}=$ stem diameter, PRI $=$ primary raceme insertion height, NSI $=$ number of stem internodes, SIL $=$ mean stem internode length, $\mathrm{PH}=$ plant height, $\mathrm{NHR}=$ number of harvested racemes, $\mathrm{PRL}=$ primary raceme length, $\mathrm{ERL}=$ effective raceme length.

The Pearson's correlation presented in Table 5 shows positive and negative correlations between the characters that can assist in explaining characteristics that contributed to lowering $\mathrm{PH}$ and in processes for future selections of other attributes of interest. The present study focused on decreasing plant height; thus, the most importat positive correlations were between the characters PH and SD (0.812) and PH and PRI (0.748), whose results were consistent with those found by Silva et al. (2017). Therefore, selecting genotypes with low heights is possible by indirect selection using SD and PRI, thus reducing the selection time and minimizing the effect of environment.

Another important data for $\mathrm{PH}$ is its strong positive correlation with NHR (0.744). These data corroborate those found by Pinto et al. (2011b), which suggest that $R$. communis plants with lower height will probably produce, individually, lower NHR. Abimiku, State and Ndor (2012) also reported positive correlations between $\mathrm{PH}$ and NHR. However, the objective of reducing plant height is to increase the yield per area due to the higher populational density, and favor mechanized harvest, as also described by Carvalho et al. (2010); Soratto et al. (2011), and Miranda et al. (2017). 
The results of the characters PRL and ERL showed a strong positive correlation between them (0.907), which is expected, since racemes with longer total lengths tend to present higher useful length. Considering 15 castor bean genotypes, Rukhsar et al. (2018) found similar positive correlation between PRL and ERL.

All evaluated characters presented high heritability, varying from 81.66 to 92.36 , for stem diameter and primary raceme length, respectively. Plant height, which was the target character of the present study, showed a heritability of 85.03. All measured characters presented $\mathrm{CVg} / \mathrm{CVe}$ higher than 1.00 , with variation from 1.241 for number of harvested racemes to 2.007 for primary raceme length, denoting a higher contribution than the environment to determine a phenotype. The characters that stood out in the correlation analysis for plant height were stem diameter and primary raceme insertion, with 0.812 and 0.748 , respectively, which were measured at the beginning of the plant cycle and is important for early selection focused on plant height.

\section{CONCLUSIONS}

Five (H17, H2, H11, H13, and H6) of the 19 hybrids evaluated have potential to decrease $\mathrm{PH}$ of castor bean plants, presenting heights below $1.07 \mathrm{~m}$. Direct selection for PH is the most indicated method due to the high heritability of the character. The characters SD and PRI are important to assist in indirect selection to decrease plant height because they can be early measured and present high heritability and strong correlation with $\mathrm{PH}$.

These results are important contributions for castor bean breeding programs focused on selection of genotypes with low plant height, and may serve as a base for further studies focused on the development of castor bean cultivars.

\section{REFERENCES}

ABIMIKU, O. E.; STATE, N; NDOR, E. Genetic Variability and Correlation Studies in Some Quantitative Characters in Castor (Ricinus communis L.). Asian Journal of Agricultural Sciences, 4: 368 $-372,2012$.

CARVAlHO, E. V. et al. Densidade de plantio em duas cultivares de mamona no Sul do Tocantins. Revista Ciência Agronômica, 41: 387-392, 2010.

CARVAlho, F. I. F. et al. Condução de populações no Melhoramento Genético de Plantas. 2. ed. Pelotas, RS: Ed. Universitária, 2008. v. 500.288 p.

CONAB - Companhia Nacional de Abastecimento, 2020. Disponível em: < http://www.conab.gov.br/> Acesso em: 28 mai. 2021.

CRUZ, C. D.; REGAZZI, A. J.; CARNEIRO, P.C.S. Modelos biométricos aplicados ao melhoramento genético. 4. ed. Viçosa, MG: UFV, 2012. 514 p.

FAO - Food and Agriculture Organization of the United Nations. FAOSTAT Statical databese. Roma: FAO, 2019. Disponível em: $68<$ http://www.fao.org/faostat/en/\#home $>$. Acesso em: 28 mai. 2021.

FORMIGA, L. A. et al. Efeito da água disponível do solo no desenvolvimento de dois cultivares de mamona, nos primeiro e segundo ciclos. Engenharia Agrícola, 34: 1128-1138, 2014.

GEBREMICHEAL, M.; NEBIYU, A.; MULUALEM, T. Estimates of Genetic Components for Yield and Quality of Cassava (Manihot esculenta Crantz) Genotypes at Jimma, Southwest Ethiopia. International Journal of Plant Breeding and Genetics, 9: 1-12, 2015.

IBGE - Instituto Brasileiro de Geografia e Estatística. Levantamento Sistemático da Produção Agrícola. 2019. Disponível em: <https:// sidra.ibge.gov.br/>. Acesso em: 28 mai. 2021.

LINS, V. D. C.; SOUSA, E. P. DE. Efeitos da produção de mamona no Ceará sob a ótica dos agricultores familiares. Novos Cadernos NAEA, 22: 27-50, 2019.

LISBOA, C. F. et al. Agronomic characteristics of common bean and castor bean hybrids in intercropping and monocropping. Revista Brasileira de Engenharia Agrícola e Ambiental, 22: 200-205, 2018 .

LIU, J. et al. The conserved and unique genetic architecture of kernel size and weight in maize and rice. Plant Physiology, 175: 774-785, 2017.

MATEUS, G. P. et al. Adubação nitrogenada em cultivares de mamona no sistema de semeadura direta consolidada. Magistra, 27: 460-467, 2015.

MILANI, M. Descritores de mamona utilizados pela Embrapa Algodão. Campina Grande, $\mathrm{PB}$ : Embrapa Algodão, 2008. 39 p.

MIRANDA, W. L. et al. Produtividade e crescimento de mamoneira em plantio adensado sob diferentes 
níveis de irrigação. Sustentare, 1: 18-28, 2017.

OLIVEIRA NETO, S. S. et al. Morphological characterization and selection of castor bean accessions for mechanized production1. Pesquisa Agropecuaria Tropical, 49: 1-9, 2019.

PASSOS, A. R. et al. Parâmetros genéticos de caracteres agronômicos em genótipos de mamoneira. Pesquisa Agropecuária Brasileira, 45: 709-714, 2010.

PINTO, C. M. et al. Correlações e análise de trilha em mamona consorciada com gergelim, algodão, milho e feijão caupi. Revista Verde, 6: 68-75, $2011 \mathrm{a}$.

PINTO, C. M. et al. Mamona consorciada com girassol em plantios defasados: análise de trilha da produtividade e seus componentes. Revista Verde, 6: 219-229, 2011b.

PIVETTA, L. G. et al. Growth performance of castor bean hybrids under different plant densities. Revista Ceres, 64: 399-412, 2017.

PUTTINI, F. A. Caracterização química e agromorfológica de genótipos de mamona (Ricinus communis L.). 2014. 110 f. Dissertação (Mestrado em Agricultura Tropical e Subtropical: Área de Concentração em Genética, Melhoramento Vegetal e Biotecnologia) - Instituto Agronômico de Campinas, Campinas, 2014.

RAMALHO, M. A. P. et al. Genética na agropecuária. 5. ed. Lavras, MG: UFLA, 2012. 565 p.

R Core Team. R: A language and environment for statistical computing. R Foundation for Statistical Computing, Vienna, Austria, 2017. URL https:// www.R-project.org/.

REZENDE, J.O. Recôncavo Baiano, berço da Universidade Federal segunda da Bahia: passado, presente e futuro. 1. ed. Salvador, BA: P\&A, 2004. $194 \mathrm{p}$.

RODRIGUES, H. C. A. et al. Avaliação da diversidade genética entre acessos de mamoneira (Ricinus communis L.) por meio de caracteres morfoagronômicos. Revista Ceres, 57: 773-777, 2010 .

RUKHSAR et al. Genetic variability, character association and genetic divergence studies in castor
( Ricinus communis L.). Annals of Agrarian Science, 16: 143-148, 2018.

SANTOS, J. B; VENCOVSKY, R. Controle genético de alguns componentes do porte da planta em feijoeiro. Pesquisa Agropecuária Brasileira, 21: 957-963, 1986.

SAVY FILHO, A. Mamona tecnologia agrícola. 1. ed. Campinas, SP: EMOPI, 2005. 105 p.

SILVA, A. R. et al. Characterization and performance of castor bean lineages and parents at the UFRB germplasm bank. PLoS ONE, 14: 1-15, 2019.

SILVA, A. R. et al. Correlations and track analysis for morphoagronomic descriptors in pedigree and parental lines of castor bean. Ciência Rural, 47: 1-7, 2017.

SORATTO, R. P. et al. Espaçamento e população de plantas de mamoneira de porte baixo para colheita mecanizada. Pesquisa Agropecuária Brasileira, 46: 245-253, 2011.

SORATTO, R. P. et al. Narrow row spacing and high plant population to short height castor genotypes in two cropping seasons. Industrial Crops and Products, 35: 244-249, 2012.

TORRES, F. E. et al. Correlations and path analysis on oil content of castor genotypes. Bioscience Journal, 31: 1363-1369, 2015.

VAZ, P. H. P. M.; SAMPAIO, Y. S. B.; SAMPAIO, E. V. S. B. Análise da competitividade da mamona e da soja para produção de biodiesel no Brasil. Revista de Economia Agrícola, 57: 35-48, 2010.

WU, L. et al. Overexpression of the maize GRF10, an endogenous truncated growth-regulating factor protein, leads to reduction in leaf size and plant height. Journal of Integrative Plant Biology, 56: 1053-1063, 2014. 